\title{
Efektivitas Penerapan Sistem E-Planning Dalam Perencanaan Pembangunan di Pemerintahan Kabupaten Tapanuli Selatan
}

\section{The Effectiveness of the Application of E-Planning Systems in Development Planning in the Tapanuli Selatan District}

\author{
Diana Rosalina Harahap*, Badaruddin \& R. Hamdani Harahap \\ Program Magister Studi Pembangunan, Universitas Sumatera Utara, Indonesia \\ Diterima: 29 Juli 2020; Disetujui: 17 Desember 2020; Dipublish: 31 januari 2021
}

\begin{abstract}
Abstrak
Penelitian ini mengangkat fenomena e-planning yang menjadi salah satu program inovasi sistem dan teknologi di pemerintahan pada masa kini. Pemerintahan Kabupaten Tapanuli Selatan melalui Badan Perencanaan Pembangunan Daerah mulai mencanangkan peneram sistem e-planning ini sejak tahun 2016. Menarik bagi peneliti untuk melihat perkembangan penerapan sistem e-planning ini yang sudah berjalan selama 4 tahun. Dalam penelitian ini, peneliti menggunakan teori efektivitas dengan pengukuran efektivitas menurut Duncan. Penelitian ini menggunakan pendekatan kualitatif dengan teknik pengumpulan data melalui observasi, wawancara, dan dokumentasi. Sedangkan, teknik analisis data menggunakan reduksi data, penyajian data, dan penarikan kesimpulan. Selama penelitian ini dilangsukan, peneliti menemukan data bahwa Pemerintah Kabupaten Tapanuli Selatan dalam hal ini BAPPEDA masih belum efektif dalam menerapkan sistem e-planning karena tidak memenuhi variable yang dijadikan syarat oleh Duncan. Adapun variable yang tidak terpenuhi adalah pencapaian tujuan dan juga adaptasi. Sementara variable yang dipenuhi adalah integrasi. Dengan adanya penelitian ini diharapkan bisa menjadi rujukan bagi Pemerintah Kabupaten Tapanuli Selatan untuk memperbaiki penerapan sistem e-planning sehingga bisa memenuhi semua syarat yang dinyatakan dalam pengukuran efektivitas Duncan.

Kata Kunci: E-planning; Duncan; Teori Efektivitas.
\end{abstract}

\begin{abstract}
This research raises the phenomenon of e-planning which is one of the systems and technology innovation programs in government today. The Tapanuli Selatan District through the Regional Development Planning Agency began implementing the e-planning system since 2016. It is interesting for researchers to see the development of the implementation of this e-planning system which has been running for 4 years. In this study, researchers used effectiveness theory with effectiveness measurement according to Duncan. This study uses a qualitative approach with data collection techniques through observation, interviews, and documentation. Meanwhile, data analysis techniques use data reduction, data presentation, and drawing conclusions. During this research, the researcher found data that the Tapanuli Selatan District, in this case BAPPEDA, was still not effective in implementing the e-planning system because it did not meet the variables that Duncan required. The unfulfilled variables are goal achievement and adaptation. Meanwhile, the fulfilled variable is integration. With this research, it is hoped that it can become a reference for the Tapanuli Selatan District to improve the implementation of the e-planning system so that it can fulfill all the requirements stated in the Duncan effectiveness measurement.
\end{abstract}

Keywords: E-planning; Duncan; Theory of Effectiveness.

How to Cite: Harahap, D.R., Badaruddin, \& Harahap, R.H. (2021). Efektivitas Penerapan Sistem EPlanning Dalam Perencanaan Pembangunan di Pemerintahan Kabupaten Tapanuli Selatan. PERSPEKTIF, 10 (1): 76-87.

\begin{tabular}{|c|c|}
\hline *Corresponding author: & ISSN $\underline{2085-0328}$ (Print) \\
\hline E-mail: badaruddin@gmail.com & (Online) \\
\hline
\end{tabular}




\section{PENDAHULUAN}

Di dalam dunia pembangunan baik di tingkat daerah, kabupaten, provinsi dan Pusat pasti mengenal istilah perencanaan. Dalam penelitian ini akan lebih banyak membahas perencanaan pembangungan di level daerah khususnya Tapanuli Selatan. Kegiatan perencanaan pembangunan tingkat daerah diartikan sebagai langkah proses merencanakan kegiatan pembangunan dengan tujuan merubah dan mengembangkan suatu daerah menjadi lebih bagus di masa yang akan datang nantinya. Keberadaan teknologi yang terus berkembang menjadikannya sebagai salah satu sumber daya potensial dan penting dalam pembangunan. Teknologi memberikan peluang untuk selalu melakukan inovasi dalam cara kerja dan juga system kerja di pemerintahan.

Teknologi yang berkembang masa ini akhirnya membantu BAPPEDA (Badan Perencanaan Pembangunan Daerah) berinovasi dengan membuat sebuah sistem informasi terpadu dibidang perencanaan dan pembangunan daerah yang tetap sinergis dengan tujuan pembangunan di tingkat nasional. Inovasi sistem tersebut adalah terbentuknya aplikasi E-Planning yang memudahkan rencana pembangunan disemua level secara administratifnya. Aplikasi E-Planning memungkinkan penyusun rencana melakukan kegiatan secara online sehingga ketika menyusun atau merubah sebuah KUA/PPAS dan RKPD baik ditingkat daerah maupun provinsi bisa lebih mudah dilakukan dan terselesaikan dengan efisien.

Adanya program Sistem e-planning telah dilakukan dibeberapa daerah di Indonesia seperti di Sulawesi Utara menerapkan sistem E-planning ini dengan menginstall aplikasinya pada website pemerintahan sehingga penginputan rencana pembangunan daerah baik jangka menengah dan panjang, proses menganalisis satuan belasn (ASB) dan SSH untuk standar satuan harga sampai pada proses penyusunan rencana kerja pemerintah Sulawesi Utara sudah bisa dilakukan secara online (Harry Patrick Paat E. F., 2018). Provinsi Sumatera Utara juga membentuk sistem aplikasi e-planning Sumut. Aplikasi e-planning dimaksud saat ini terbagi dalam dua model pengembangan yaitu berbasis desktop untuk mengelola data perencanaan daerah lima tahunan (RPJMD dan Renstra) dan berbasis web untuk pengelolaan perencanaan daerah tahunan.

Berkaca dari Provinsi Sumatera Utara, maka Pemerintahan Kabupaten Tapanuli Selatan juga mengikut perkembangan teknologi dan system dalam tatanan pemerintahannya. Sejak Tahun 2016 sudah direncanakan untuk memulai penerapan sistem e-planning tersebut di pemerintahan. Untuk mensuksekan program ini maka, Pemerintah Kabupaten Tapanuli Selatan memulai perencanaan ditingkat kecamatan. Hal ini merupakan langkah awal agar bisa mendata dan menginput perancanaan masing-masing kecamatan dalam sistem e-planning ini. Masing-masing kecamatan akan memasukkan perencaan tersebut kedalam sistem ini. Namun untuk proses Musrenbang mulai dari tingkat desa, kecamatan dan kabupaten masih dilakukan secara manual.

Adanya sistem e-planning yang sekarang sedang dikembangkan di daerahdaerah demi mencapai tujuan untuk mengarahkan pembangunan di semua tingkat pemerintah dari terendah hingga tertinggi arah sesuai dengan apa yang dibutuhkan masyarakat sehingga nantinya rencana-rencana pembangunan yang dibuat tidak lagi salah sasaran dan menguntungkan pihak-pihak tertentu saja. Hal ini penting diwujudkan karena cerminan dari pembangunan daerah yang benar adalah proyeksi dari apa yang benarbenar masyarakat daerah butuhkan untuk memperbaiki dan meningkatkan kualitas hidup mereka dalam konteks berbangsa dan bernegara. 
Dalam penelitian ini memfokuskan pada Pemerintahan Kabupaten Tapanuli Selatan yang masih dalam proses penerapan program tersebut hanya menjalankan E-Renja dan E-Musrenbang saja, sehingga dalam penelitian ini akan membahas kedua aspek tersebut. E-Renja adalah Sistem Informasi Perencanaan Pembangunan Berbasis Elektronik Terintegrasi adalah sebuah alat penyusunanan Renja OPD, Renstra OPD, RKPD, s/d KUA-PPAS agar dapat terselesaikan dengan mudah, cepat, tepat dan sesuai dengan arahan yang terkandung dalam Permendagri No. 86 Tahun 2017 tentang tata cara perencanaan, pengendalian dan evaluasi pembangunan daerah. E-Musrenbang adalah Aplikasi pendukung kegiatan Musrenbang Provinsi dan Penyusunan RKPD Provinsi serta penyelarasan program \& kegiatan prioritas pembangunan daerah Povinsi dengan Nasional, RPJMD Provinsi dan RTRW Provinsi (eplanning.sumutprov)

Dalam proses implementasi sebuah program, terutama program atau kebijakan - kebijakan yang baru tidaklah mudah. "Efektivitas Sistem Perencanaan Pembangunan Daerah (Simrenda) Studi Pada Badan Perencanaan Pembangunan Daerah Kota Malang"oleh Budhi Setianingsih, dkk yang melihat penerapan sistem aplikasi Simrenda tidak sepenuhnya berjalan baik dan efektivitasnya masih rendah. Ini bisa terjadi tentu saja karena ada penyebabnya yaitu perangkat daerah tidak menidentifikasi kendala-kendala di daerah sehingga penerapan sistem ini untuk pembangunan terhambat, belum lagi staff BAPPEDA yang kurang berkualitas dan terakhir disebabkan oleh hasil pembangunan yang tidak memuaskan warga di kota malang itu sendiri (Budhi Setianingsih, 2015). Meskipun sama-sama membahas tentang e-planning namun yang membedakan adalah programnya dimana peneliti berfokus pada musrenbang dan juga renja. Selain itu teori yang digunakan juga berbeda sehingga bisa memaparkan fenomena yang sama dengan pandangan yang berbeda. Penelitian terdahulu ini fokus pada aspek Satuan waktu, Satuan hasil, Kualitas kerja dan Kepuasan masyarakat sebagai tolak ukur efektivitas dari programnya.

Banyaknya hambatan dan kendala yang menjadikan sebuah program tidak berjalan dengan semestinya. Biasanya dasar permasalahan yang terjadi dalam merencanakan sebuah pembangunan adalah cara berfikir yang masih linier atau ke satu arah saja (top down model) yang memicu tidak terlihatnya isu-isu dan masalah di level masyarakat di daerah tersebut sehingga kepentingan mereka tidak teakomodir oleh pembangunan yang dilakukan (Azis, 2013).Fenomena tersebut memberikan dorongan pada peneliti untuk mengangkat tema penerapan system eplanning di Kabupaten Tapanuli Selatan. Selain itu, tema ini menjadi menarik untuk diteliti karena efektivitas dan kesuksesan implementasi sebuah program menjadi hal penting yang harus di capai.

Jika program ini di jalankan dengan baik dan efektif oleh Kabupaten Tapanuli Selatan maka akan menjadi percontohan yang baik serta membuktikan bahwa kinerja aparat juga baik. Namun sebaliknya, jika program ini belum diterapkan secara maksimal, maka sebagai peneliti dapat memberikan bahan evaluasi dan saransaran yang dapat di terapkan untuk mensukseskan program ini. Apalagi sejak 4 tahun lalu program ini sudah dimulai, penting untuk melihat sejauh apa pencapaian implementasi dari program ini agar menjadi pembelajaran bagi saya sebagai peneliti berkaitan dengan teoriteori dan fenomena yang dipelajari maupun bagi institusi pemerintahan sebagai pelaksana program. Peneliti juga tertarik untuk melihat bagaimana respon dari masyarakat sebagai objek yang terlibat dalam program ini. Kepuasan masyarakat sangatlah penting sebagai salah satu tolak ukur bahwa program ini berjalan dengan baik. 


\section{METODE PENELITIAN}

Metode penelitian yang peneliti pilih adalah deskriptif dengan menggunakan pendekatan bersifat kualitatif. Metode deskripsi tidak dimaksudkan menjadi alat pengujian hipotesa penelitian, jadi posisinya hanya memberikan gambaran secara mendalam atas variabel, fenomena atau keadaan.

Informan penelitian ini di pilih dengan cara purposive sampling yaitu penentuan informan dengan kriteria-kriteria yang sudah ditetapkan sehingga akan bisa mendapatkan informasi sesuai yang detil. Kriterianya antara lain adalah yang berhubungan langsung dengan program eplanning ini diaktegorikan sebagai informan kunci. Sementara yang tidak berhubungan langsung dengan program ini adalah informan pendukung. Sehingga Informan dalam penelitian ini adalah:

1. Informan kunci adal subjek penelitian utama dan pertama yang langsung terlibat dalam kegiatan atau program yang diteliti sehingga informan kunci dalam penelitian ini adalah Kepala Bappeda sebanyak 1 orang dan Kepala Bidang Penelitian dan Pengembangan 1 orang dan 2 orang Programer Senior $E$ Planning.

2. Informan Pendukung merupakan subjek penelitian tidak langsung dimana perananannya tidak terlibat secara besar dalam program atau kegiatan yang diteliti namun masih memiliki hubungan dan informasi atas kegiatan tersebut sehingga yang menjadi informan tambahan, pada penelitian ini adalah 2 orang Perwakilan Kasubbag Perencanaan di kecamatan.

Data yang dikumpulkan dalam penelitian ini dapat dikelompokkan oleh penulis menjadi dua jenis, yaitu: Data primer merupakan data langsung yang didapatkan dari key informent terkait dengan kegiatan yang diteliti. Menurut (Irawan, 2004), data primer secara langsung dikumpulkan dari sumber-sumber valid. Sumber ini dapat berupa bendabenda, situs atau manusia. Dalam hal ini, peneliti menggunakan sumber dari manusia melalui wawancara. Selanjutnya menurut (Moleong, 2004) metode wawancara merupakan jenis komunikasi yang didalamnya terdapat percakapan antara yang mewawancarai dengan yang akan diwawancarai melalui daftar pertanyaanpertanyaan yang dibuat berkaitan dengan fenomena yang diteliti.

Data sekunder menurut (Irawan, 2004) merupakan data tidak langsung yang diperoleh melaui sumber lainnya. Jadi data sekunder adalah data yang diperoleh dengan telaah dokumentasi/dokumen atau mengkaji buku-buku atau dokumen penting yang berkaitan dan mendukung penelitian. Oleh sebab itu, kualitas penelitian ini juga sangat tergantung kepada kualitas dokumen-dokumen yang dikaji. Hal ini dilakukan dengan cara mengkaji laporanlaporan maupun dokumen resmi lainnya yang berkaitan dengan penelitian, seperti peraturan perundang-undangan, arsiparsip dan hasil musrenbang di Kabupaten Tapanuli Selatan. Dengan teknik pengumpulan data ini diharapkan penulis akan mendapatkan data yang mempunyai validitas dan reabilitas yang tinggi sehingga data yang diperlukan tersebut representatif.

Analisa secara deskriptif adalah Teknik Analisa data yang digunakan peneliti dalam melihat temuan data selama penelitian ini. Kedua data baik primer dan sekunder semuanya dianalisisi sesuai dengan Teknik Analisa yang peneliti gunakan dalam proses penelitian. Langkah selanjutnya adalah peneliti mencoba untuk menginterpretasi temuan data dilapangan untuk kemudian dilaporkan dan dijabarkan secara terperinci.

\section{HASIL DAN PEMBAHASAN}

Pada Pasal 1 Permendagri Nomor 98 Tahun 2018; mendefinisikan E-Planning atau Perencanaan Berbasis Elektronik 
sebagai berikut : Aplikasi yang digunakan untuk membantu perumusan kebijakan dalam penyusunan dokumen rencana pembangunan daerah berbasis daring. Berdasarkan uraian tersebut e-planning dapat dikatakan merupakan bagian dari SIPD. Sistem E-Planning ini nantinya akan berisi tentang menu-menu RPJMD selama 5 tahunan Bersama Rencana Kerja Tahunan (RKPD) yang dimanifestasikan dalam Renstra dan Renja SKP disertai dengan laporan-laporan yang digunakan dalam penyusunan dokumen SKPD dan Pemerintah Daerah.

Dalam mengukur efektivitas menurut Duncan maka hal yang penting untuk dilihat adalah waktu pencapaian tujuannya. Hal ini berkaitan dengan waktu, sasaran dan tujuan, serta dasar-dasar hukum pelaksanaannya. Mengaitkan poin-poin tersebut dengan program e-planning maka untuk waktu pencapaian tujuan bapak Abadi Siregar, ST, MT Kepala Badan Perencanaan Pembangunan Daerah Kabupaten Tapanuli Selatan menjelaskan bahwa sejak tahun 2016 program ini sudah mulai dibahas dan dirumuskan di Pemerintahan Kabupaten Tapanuli Selatan. Sebelumnya, proses perencanaan pembangunan di Kabupaten Tapanuli Selatan belum menggunakan sistem

\begin{tabular}{|c|c|c|c|c|c|c|}
\hline Outcome & $\begin{array}{l}\text { Target } \\
\text { Tahun } \\
2016 \\
(\%)\end{array}$ & $\begin{array}{l}\text { Target } \\
\text { Tahun } \\
2017 \\
(\%)\end{array}$ & $\begin{array}{l}\text { Target } \\
\text { Tahun } \\
2018 \\
(\%)\end{array}$ & $\begin{array}{l}\text { Target } \\
\text { Tahun } \\
2019 \\
(\%) \\
\end{array}$ & $\begin{array}{l}\text { Target } \\
\text { Tahun } \\
\mathbf{2 0 2 0} \\
(\%)\end{array}$ & $\begin{array}{l}\text { Target } \\
\text { Tahun } \\
2021 \\
(\%) \\
\end{array}$ \\
\hline $\begin{array}{l}\text { Terbangunnya Sistem Aplikasi } \\
\text { E- } \\
\text { Planning yang terintegrasi }(\%)\end{array}$ & $\mathrm{O}$ & 40 & 70 & 80 & 90 & 100 \\
\hline $\begin{array}{llr}\text { Terimplementasikannya } & \text { Aplikasi } & \text { E- } \\
\text { Planning Dalam } & \text { Perencanaan } \\
\text { Pembangunan Daerah (\%) } & & \end{array}$ & o & 40 & 70 & 80 & 90 & 100 \\
\hline
\end{tabular}

informasi atau masih bersifat manual,

Tabel 1.1 Target Outcome Penerapan Sistem E-Planning BAPPEDA Kabupaten Tapanuli Selatan Sumber: Data Rencana Kegiatan BAPPEDA olahan peneliti: 2020

Berdasarkan data di atas peneliti menyimpulkan bahwa pencapaian tujuan dalam implementasi sistem e-planning 
belum memiliki keterikatan waktu pencapaian (time bound). Karena outcome sampai tahun 2020 ini tidak memenuhi target rencana kerja dari BAPPEDA itu sendiri. Dengan belum adanya keterikatan atau batas waktu pencapaian anatara perencanaan program e-planning dan implementasi e-planning maka kegiatan akan berjalan tidak efektif. Nantinya akan sulit bagi BAPPEDA untuk melakukan penilaian terhadap kinerja atau Penilaian terhadap program ini apakah sudah berhasil atau belum berhasil karena tidak sesuai dengan target yang ditentukan. Selain itu, target capaian waktu yang tidak jelas akan membuat pekerjaan tidak maksimal. Menurut (Duncan, 1985) waktu yang ditentukan untuk mencapai atau menyelesaikan sebuah program haruslah jelas agar pengukuran efektivitasnya bisa dilakukan. Jika sebuah program tidak memiliki target penyelesaian yang tertulis jelas maka pengukuran efektivitas pelaksanaan tidak bisa dilakukan. Dalam hasil penelitian ini menunjukan bahwa Pemerintah Kabupaten Tapanuli Selatan dalam hal ini BAPPEDA meskipun memiliki target pencapaian tujuan namun tidak berjalan sesuai dengan target tersebut sehingga tidak memenuhi apa yang diakatakan oleh teori efektivitas menurut Duncan.

Sementara dalam hasil wawancara lanjutan dengan Bapak Abadi terkait dari sasaran dan tujuan sistem e-planning ini peneliti melihat bahwa sebagai pelaksana kebijakan, Bapak Abadi sangatlah memahami secara menyeluruh mengenai program e-planning ini. Pemahaman yang baik ini tentulah membantu instansi ini untuk bisa melaksanakan program dengan tepat. Dengan adanya sistem e-planning ini memungkinkan meningkatkan poin akuntabilitas dan transparansi di masyarakat. Menurut Bapak Abadi, hal ini penting untuk menghilangkan stigma buruk dimasyarakat bahwa personal ataupun instansi yang terkait dengan pemerintah seringkali membuat pembagunan dan perencanaan yang tidak jelas. Belum lagi menurutnya, isu korupsi juga marak dan menambah citra negatif dimasyarakat.

Dengan mengimplementasikan Perencanaan Pembangunan Daerah Berbasis e-planning pada BAPPEDA Kabupaten Tapanuli Selatan dapat membantu efisiensi serta efektivitas kinerja BAPPEDA, yaitu: 1) Meningkatkan/mendorong implementasi sistem perencanaan (e-planning), emusrenbang dan e-renja secara penuh dalam penyusunan penganggaran pemerintah daerah; 2) Meningkatkan kapasitas dan kapabilitas sumber daya Pemerintah Daerah dengan melakukan bimbingan teknis, workshop, dan asistensi sistem perencanaan pembangunan daerah.

Menurut Badan Pembinaan Pengelolaan Keuangan Pemerintah Daerah (BPPKPD) adapun maksud, sasaran dan manfaat dari program e-planning ini meliputi (bppkd)

Maksud: Memanfaatkan teknologi informasi dan komunikasi yang tersistematis dan bersifat aplikatif terhadap perencanaan pembangunan daerah sehingga membantu mewujudkan integrasi dokumen-dokumen perencanaan menengah dan tahunan yang kualitasnya baik

Tujuan: Secara umum tujuan penyusunan sistem informasi perencanaan pembangunan daerah adalah: 1) Menciptakan integrasi antara rencana program dan anggaran di daerah dengan sistem online dan offline; 2) Membentuk interaksi sistem informasi dan komunikasi yang meluaskan hubungan pemda dengan masyarakat daerah yang berkaitan dengan pembangunan daerah; 3) Meningkatkan image dari perangkat daerah atau pemerintahan yang mengabdikan diri pada negara dan berkomitmen melayani masyarakat denagn professional dengan mengutamakan prinsip efektivitas dan efisiensinya; 4) Memudahkan perangkat daerah atau pemerintah untuk memiliki 
database informasi yang utuh terkait rencana pembangunan pemerintah daerah.

Sasaran: Aplikasi ini ingin mewujudkan sistem kordinasi dan komunikasi yang efisien dan efektif bagi perangkat daerah dan pemerintah terkait perencanaan pembangunan daerah diberbagai tingkatan mulai dari daerah sampai pusat. Dengan adanya teknologi ini maka kemudahan untuk aksesnya akan lebih baik dan akuntabilitasnya juga bisa dilaksanakan dengan baik sehingga rencana pembangunan lebih lebih terarah, keterpaduan, sinergisitasnya tinggi, tepat waktu sesuai yang ditargetkandan berkesinambungan.

Manfaat: Adapun manfaat dari sistem e-planning ini yaitu: 1) Memberi bantuan pada Bappeda dan satuan kerja perangkat daerah membuat rumusan perencanaan kerja berdsarkan usulan yang ada pada musrenbang; 2) Memberi bantuan pada Bappeda dan satuan kerja perangkat daerah menentukan berbagai indikator untuk mengukur hasil kerja yang berkesinambungan, realistis dan tepat; 3) Memberi bantuan pada Bappeda dan satuan kerja perangkat daerah untuk penyusunan rencana-rencana keja jangka menengah dan tahunan berdasarkan target - target yang sudah ditentukan; 4) Memberi bantuan pada Bappeda dan satuan kerja perangkat daerah sosialisasi dokumen dan publikasinya terkait rencana pembangunan daerah sampai pusat.

Duncan memaparkan dalam teorinya bahwa sasaran merupakan target yang konkret atau nyata, bukan sebuah target yang tidak jelas (Duncan, 1985).Kejelasan target ini akan mempengaruhi pelaksana dalam menerap kan program ini. Dikaitkan dengan tema yang peneliti angkat mengenai sistem e-planning di Kabupaten Tapanuli Selatan, Bapak Abadi dengan sangat jelas memaparkan sasaran dan tujuannya sehingga bisa disimpulkan aspek ini sudah dipenuhi oleh programnya. Selain itu dari data BPPKPD juga sudah sangat lengkap memaparkan maksud, tujuan, sasaran dan maanfaat dari e-planning.

Aspek terakhir yang tidak kalah penting dalah dasar hukum dalam melaksanakan e-planning ini. Menurut Bapak Abadi, Pemerintahan Kabupaten Tapanuli Selatan khususnya BAPPEDA menerapkan sistem e-planningsesuai arahan Peraturan Mentri Dalam Negeri No 86 tahun 2017 dan semua daerah juga pasti menggunakan peraturan ini sebagai rujukan. Bapak Abadi menambahkan lagi bahwa dalam peraturan itu juga dibahas tentang fase-fase e-planningcontohnya pada fase 0 (persiapan) dalam mengumpulkan data dan informasi pembangunan; fase 2 (strategi) pada saat pemasukan dan verifikasi usulan Musrenbang RPJMD; dan fase 4 (integrasi), yaitu mengintegrasikan misi, tujuan, sasaran, sampai pada program daerah dengan Organisasi Perangkat Daerah.

Menurut peneliti, jawaban yang diberikan oleh Bapak Abadi selama wawancara memanglah sudah tepat. Pembahasan mengenai dasar hukum ini sebenarnya dimulai dari komitmen yang dilakukan pemerintah dengan perubahan Undangundang Nomor 22 Tahun 1999 menjadi Undang-undang Nomor 32 Tahun 2004 yang kini telah kembali direvisi menjadi Undang-undang Nomor 23 Tahun 2014 tentang Pemerintah Daerah dan Undang-undang Nomor 25 Tahun 1999 yang direvisi menjadi Undang-undang Nomor 33 Tahun 2004 tentang Perimbangan Keuangan antara Pemerintah Pusat dan Pemerintah Daerah. Lalu dalam perkembangan selanjutnya, pada tataran teknis perencanaan pembangunan ditingkat daerah secara lebih khusus diatur dalam Peraturan Menteri Dalam Negeri Nomor 86 Tahun 2017. Secara garis besar penyusunan perencanaan pembangunan dimulai dengan adanya proses persiapan, penyusunan rancangan awal sampai akhir, musrenbang, forum konsultasi publik dan perangkat daerah, sampai pada penetapan peraturan daerah. Proses perencanaan 
inilah yang dulu dilakukan secara manual mulai dikembangkan dengan teknologi melalui sistem e-planning yang sekaramg juga diterapkan oleh Pemerintahan Kabupaten Tapanuli Selatan. Secara lebih detail, Penggunaan sistem informasi ( $e$ planning) pada perencanaan tingkat daerah tercantum pada Permendagri Nomor 86 Tahun 2017 pasal 14 ayat (3); yang menyebutkan penyusunan RPJPD, RPJMD, dan RKPD dilakukan berbasis e-planning dan Undang-undang Nomor 23 Tahun 2014 tentang Pemerintahan Daerah pasal 274 dan pasal 391. Berdasarkan aturan diatas maka aspek landasan hukum yang dinyatakan (Duncan, 1985)sebagai pondasi pelaksanaan program juga sudah terpenuhi.

Peneliti menyimpulkan bahwa sesuai dengan ukuran efektivitas yang diteorikan (Duncan, 1985)untuk variable yang pertama yaitu pencapaian tujuan masih belum terpenuhi secara keseluruhan oleh BAPPEDA Kabupaten Tapanuli Selatan baik untuk e-musrenbang dan e-renja. 2 indikator yaitu sasaran dan landasan hukum sudah terpenuhi namun untuk 1 indikator lainnya yaitu waktu pencapaian belum terpenuhi.

\section{Integrasi}

Duncan melihat bahwa dalam mengukur efektivitas sebuah organisasi dalam mengimplementasikan programnya maka harus terintegrasi baik terutama dengan pihak luar Dalam program $e$ planning ini tidak hanya peranan BAPPEDA Kabupaten Tapanuli Selatan saja yang diperlukan tetapi juga harus melibatkan banyak pihak lain seperti lembaga perencanaan di kecamatan dan Organisasi Perangkat Daerah (OPD) lainnya. Bapak Ronni Oktorio, S. Hut sebagai Kepala Bidang Penelitian dan Pengembangan pada Badan Perencanaan Pembangunan Daerah Kabupaten Tapanuli Selatan yang langsung bertanggung jawab terhadap implementasi program e-planning ini di lingkungan Pemerintah Kabupaten Tapanuli Selatan menjelaskan bahwa dari pihaknya sudah membuat prosedur panduan dalam bentuk buku untuk mempelajari e-planning terutama sistem dan cara pengoperasiannya. Buku panduan ini sebagai salah satu media atau alat bantu komunikasi untuk menginformasikan semua hal berkaitan dengan e-planning sehingga pihak lainnya juga bisa memahaminya. Buku Panduan tersebut adalah Panduan Penginputan Renja $e$ planning yang berisi materi tentang cara masuk, cara upload dan cara penyelesaiannya.Denganadanya buku panduan tersebut, Bapak Ronni berharap dapat sedikit membantu semua pihak dalam mempelajari sistem e-planning tersebut. Bapak Irwansyah Siagian, SKM Kasubbag Perencanaan pada Kecamatan Batang Angkola menambahkan bahwa buku panduan tersebut juga sudah didistribusikan dan diguanakan sebagai buku panduan dan bahan untuk sosialisasi kepada staffnya di Kantor Kecamatan Batang Angkola.

Peneliti melihat dokumen buku panduan tersebut dan mempelajarinya dan menyimpulkan sudah jelas sekali dipaparkan mengenai prosedur pelaksanaan atau penginputan rencana kerja. Dari daftar isi juga sudah bisa terlihat bahwa setiap poin-poin pentingnya seperti cara mengakses, halaman $\log$ in, tampilan sistem e-renja, cetak renja awal, input rancangan renja OPD, verifikasi rancangan renja OPD, Verifikasi hasil musrenbang kecamatan, penyempurnaan renja kecamatan dan cetak hasil penyempuranaan renja kecamatan. Peneliti berusaha melihat secara lebih detail dari buku panduan yang diterbitkan oleh BAPPEDA Kabupaten Tapanuli Selatan dan menyimpulkan bahwa memang didalam buku tersebut sudah memuat prosedur penggunaan sistem e-planning dengan jelas. Selain itu ada gambar-gambar yang ditampilkan mulai dari gambar halaman depan websitenya, gambar menu-menu di sistem dan juga gambar penjelasan dari 
setiap proses yang dilakukan untuk membuat rancangan rencana kerja dan musrenbang samapai pada tahapan verifikasinya juga. Namun peneliti setuju dengan pendapat bapak Irwansyah bahwa memang buku panduan ini cukup membantu namun hanya sebagai pengenalanan dan pemahaman awal. Untuk peingkatan kemampuan masih perlu dilakukan bimbingan teknis maupun diklat khusus.

\section{Adaptasi}

Ketika sebuah organisasi menerapkan sebuah sistem dan program yang baru maka tidak serta merta menjadikan organisasi tersebut mampu menjalankanya dengan baik. Selama masa perencanaan program tersebut sampai pada tahapan implementasi dan evaluasilah terjadi proses adaptasi. Proses adapatasi tersebut tidak hanya dilakukan oleh para pelaksana kebijakan dalam hal ini adalah manpower yaitu Pegawai Pemerintahan Kabupaten Tapanuli Selatan khususnya BAPPEDA saja tetapi juga adaptasi dalam bentuk fisik berupa sarana dan prasarana juga (Duncan, 1985). Duncan menjelaskan bahwa hubungan antara penyesuaian diri terhadap perubahan berbanding lurus dengan keberhasilan organisasi. Jika proses adpatasi cepat dan berhasil dilakukan maka organisasi tersebut berhsil megatasi perubahan, namun sebaliknya jika proses adaptasi lambat dan gagal maka organisasi tersebut menjadi korban dari perubahan. Dalam mengukur keberhasilan adaptasi ini bisa dilihat dari pengembangan kemampuan pegawai di BAPPEDA Kabupaten Tapanuli Selatan dan juga dari penyesuaian sarana dan prasarana yang dibutuhkan untuk menerapkan e-planning ini.

Indikator adaptasi bagian pengembangan kemampuan masih belum terpenuhi secara menyeluruh. Peneliti melihat meskipun ada peningkatan pengetahuan tanpa adanya bimtek tetap tidak maksimal ini dilihat dari wawancara dengan Bapak Hasanuddin dan Ibu Yenni yang mengatakan merasa kebingungan di awal dan juga tidak cukup hanya belajar dengan buku panduan dan sharing saja. Menurut mereka, hasil kerja mereka akan maksimal jika ada bimtek yang membantu mereka paham secara lebih mendalam, selain itu bimtek juga bisa meminimalisir kesalahan kerja yang dilakukan.

Selanjutnya Indikator adaptasi mengenai sarana dan prasarana yang disediakan untuk kelancaran penerapan program e-planning ini. Menurut Duncan, pengembangan kemampuan saja yang ditingkatkan tidak akan berhasil untuk adapatasi dengan perubahan jika tidak disertai dengan adaptasi sarana prasarana yang menunjang (Duncan, 1985). Sebaliknya jika hanya aspek sarana prasarana saja yang terpenuhi namun aspek pengembangan kemampuan staff organisasinya dalam menghadapi perubahan tidak baik maka sarana-dan prasarana tersebut hanya akan sia-sia dan tidak bisa digunakan dengan maksimal. Ronni Oktorio, S.Hutsebagai Kepala Bidang Penelitian dan Pengembangan pada Badan Perencanaan Pembangunan Daerah Kabupaten Tapanuli Selatan menyatakan bahwa sarana dan prasarana sudah memadai. Data asset untuk computer di divisi litbang berjumlah 2 unit dan 4 unit laptop dengan kondisi yang bagus dan menurut Bapak Ronni jumlah tersebut sudah memadai untuk digunakan oleh 3 orang programmer senior e-planning

Meskipun jumlah asset sudah cukup memadai secara kuantitas namun secara kualitas masih ada yang belum baik yaitu jaringan internet atau jaringan computer yang sangat penting dalam sistem $e$ planning ini. Hal ini sesuai dengan hasil wawancara bahwa kondisi laptop dan computer sudah baik namun jaringan masih belum stabil dan pernah ada kejadian dimana gagal upload berkas serta proses verifikasi hasil musrenbang yang eror dikarenakan jaringan rusak dan hilang Kondisi ini membuat pekerjaan tertunda 
dan harus menambah beberpa hari lagi untuk menyelesaikan pekerjaan tersebut. Yenni menambahkan bahwa penyebab hal ini terjadi bisa karena power outage atau listrik padam mendadak sehingga jaringan terputus tiba-tiba dan juga bisa karena data centerdown sehingga menjadi crash sering terjadi meskipun sudah menggunakan server 1 buah HPE proliant dengan kapasitas 1 Terra Byte.

Berbagai penjalasan diatas membuktikan bahwa aspek adaptasi masih belum terpenuhi baik dari indikator pengembangan kemampuan dan juga sarana prasarana untuk e-renja dan emusrenbang. Duncan menekankan bahwa pengukuran efektivitas sebuah organisasi dalam menghadapi perubahan harus terpenuhi semuanya tanpa terkecuali (Duncan, 1985). Untuk variable pertama yaitu pencapaian tujuan dengan 3 indikator yaitu waktu pencapaian, sasaran dan tujuan serta terakhir dasar hukum maka yang tidak terpenuhi adalah waktu pencapaian tujuan. Variable kedua yaitu integritas dengan indikator prosedur pelaksanaan program dan sosialisasi sudah terpenuhi semua namun menjadi catatn adalah pemanfaatan sosialisasi digital yang belum diterapkan oleh BAPPEDA Kabupaten Tapanuli Selatan. Variabel Ketiga yaitu Adaptasi dengan indikator pengembangan kemampuan dan sarana prasarana juga belum terpenuhi. Berdasarkan temuan penelitian tersebut maka bisa disimpulkan bahwa penerapan sistem e-planning di Pemerintahan Kabupaten Tapanuli Selatan belum efektif.

\section{Hambatan Penerapan Sistem E-Planning di Pemerintahan Kabupaten Tapanuli Selatan}

Dari data - data temuan dilapangan selama meneliti penerapan sistem $e$ planning di pemerintahan Kabupaten Tapanuli Selatan ini peneliti menemukan bahwa variable-variabel pengukuran efektivitas yang tidak dipenuhi oleh BAPPEDA Kabupaten Tapanuli Selatan menurut Duncan merupakan faktor penghambat atau kendala yang menyebabkan penerapan sistem e-planning ini tidak efektif. Adapaun variable yang menjadi kendala tersebut meliputi:

1. Variable pencapaian tujuan yang terdiri dari 3 indikator yaitu waktu mencapai tujuan, sasaran dan tujuan, serta dasar hukum yang tidak terpenuhi ada di indikator waktu pencapaian tujuan. Meskipun sudah memiliki target capaian atau outcome yang direncanakan namun hal ini masih belum tercapai bahkan jauh meleset dari apa yang ditargetkan. Ini terjadi karena berkaitan dengan variable selanjutnya mengenai sarana prasara pendukun penerapan sistem e-planning dan juga kurangnya pemahaman dan pengembangan staff di BAPPEDA.

2. Dalam wawancara dengan Ronni Oktorio, S.Hut sebagai Kepala Bidang Penelitian dan Pengembangan pada Badan Perencanaan Pembangunan Daerah Kabupaten Tapanuli Selatan mengatakan bahwa berharap adanya bimbingan teknis atau diklat untuk memantapkan pengetahuan staff dan timnya. Meskipun informasi bisa didapat melalui saharing dan buku panduan namun bimbingan teknis perlu dilakukan bahkan tidak hanya untuk internal BAPPEDA tetapi juga dengan OPD yang terlibat dalam menerapk sistem ini. Ini bisa dilakuakn dengan megundang narasumber yang tepat seperti Pemerintahan Kota Surabaya yang memang BAPPEDA Kabupaten Tapanuli Selatan ini mengadopsi sistemnya dari sana. Hal senada juga diungkapkan oleh Mhd. Hasanuddin, S.Kom sebagai Programer Senior $E$ Planning pada Badan Perencanaan Pembangunan Daerah Kabupaten Tapanuli Selatan pernah mendapati banyaknya file yang salah upload, banyaknya OPD yang bingung dengan sistem e-planning ini sehingga perlu diadakan Bimtek untuk mendukung pemahaman yang merata. Hal ini membuktikan bahwa pengembangan 
kemampuan masih minim dijajaran pelaksana sistem ini baik dari BAPPEDA dan OPD. Pelaksanaan sosialiasi tidak mampu mengakomodir peningkatan kemampuan, sosialisasi yang dilakukan BAPPEDA hanya sebatas memberikan pemahaman awal tentang sistem $e$ planning atau dikenal dengan introducing saja.

3. Kendala yang menghambat penerapan sistem e-planning di Pemerintahan Kabupaten Tapanuli Selatan yang terakhir adalah sarana-prasarana. Tidak stabilnya jaringan adalah masalah utama yang emmang dihadapi semua program jika berkaitan dengan sistem online. Mhd. Hasanuddin, S.Kom selaku Programer Senior E-Planning pada Badan Perencanaan Pembangunan Daerah Kabupaten Tapanuli Selatan menambahkan bahwa masalah jaringan memang menjadi tugas besar dari timnya terkait dengan server yang down atau crash. Pekerjaan bisa terhambat, dan perlu tambahan waktu ekstra untuk penyelsaian pekerjaan terkait upload dokumen, penyesuaian dan verifikasi renja dan musrenbang jika jaringan tidak stabil. Dengan adanya data atas kendala penerapan sistem e-planning di Pemerintahan Kabupaten Selatan yang menjadi penghambat efektivitas implementasinya ini, diharapkan bisa menjadi focus utama dari BAPPEDA Kabupaten Tapanuli Selatan untuk menyelesaikannya agar nantinya penerapan sistem e-planning bisa berjalan efektif dan seusuai dengan capaian target yang ditentukan oleh BAPPEDA.

\section{SIMPULAN}

Berdasarkan kerangka pemikiran yang sudah peneliti buat maka penerapan sistem e-planning dalam program pembangunan daerah oleh Badan Perencanaan dan Pembangunan Daerah Kabupaten Tapanuli Selatan ini belum efektif karena belum memenuhi semua variable pengukuran efektivitas menurut Duncan.Adapun variabel yang tidak terpenuhi adalah variabel pencapaian tujuan yaitu waktu capaian dan variabel adapasi yaitu pengembangan kemampuan dan juga sarana dan prasarana. Variabel-variabel yang tidak terpenuhi inilah yang kemudian menajdi faktor penghambat atau kendala BAPPEDA Kabupaten Tapanuli Selatan dalam menerapkan sistem e-planning.

\section{DAFTAR PUSTAKA}

Duncan, J. W. (1985). Organization Behavior. Boston: Houghton Mifflin.

Irawan, P. (2004). Logika dan Prosedur Penelitian. Jakarta: STIA-LAN Press.

Moleong, L. J. (2004). Metode Penelitian Kualitatif. Bandung: Remaja Rosdakarya.

Sugiyono. (2007). Statistik Untuk Penelitian. Bandung: Alfabeta, cv.

Azis, A. B. (2013). Analisis Perencanaan Pembangunan Daerah dengan Pendekatan Sistem Lunak (Soft System) (Studi Pada Rencana Kerja Pembangunan Daerah (RKPD) Kaupaten Balangan). E-Journal Fakultas Ilmu Administrasi Universitas Brawijaya .

Harry Patrick Paat, Edward Fredrik Tuju, Meily Y. B Kalalo. (2018). Ipteks Implementasi Perencanaan Pembangunan Daerah Berbasis E-Planning Pada Badan Perencanaan, Jurnal Ipteks Akuntansi bagi Masyarakat , 02 (02), 11-15.

Budhi Setianingsih, E. S. (2015). Budhi Setianingsih, Efektivitas Sistem Perencanaan Pembangunan Daerah (Simrenda) (Studi pada Badan Perencanaan Pembangunan Daerah Kota Malang), Jurnal Administrasi Pulik(JAP) , 3 (11), 1930-1936.

Peraturan Menteri Dalam Negeri Republik Indonesia Nomor 86 Tahun 2017 Tentang Tata Cara Perencanaan, Pengendalian Dan Evaluasi Pembangunan Daerah, Tata Cara Evaluasi Rancangan Peraturan Daerah Tentang Rencana Pembangunan Jangka Panjang Daerah Dan Rencana Pembangunan Jangka Menengah Daerah, Serta Tata Cara Perubahan Rencana Pembangunan Jangka Panjang Daerah, Rencana Pembangunan Jangka Menengah Daerah, Dan Rencana Kerja Pemerintah Daerah.

Undang-undang Republik Indonesia Nomor 25 Tahun 2004, Tentang Sistem Perencanaan Pembangunan Nasional.

Undang-undang Republik Indonesia Nomor 32 Tahun 2004, Tentang Pemerintahan Daerah. 
sumutprov.

https://eplanning.sumutprov.go.id/backend /web/index.php . Retrieved Juni 10, 2020, from sumutprov: https://eplanning.sumutprov.go.id/backend /web/index.php

bppkd. (n.d.). www.bppkd.com. Retrieved Juni 10, 2020, from www.bppkd.com/layananaplikasi/e-planning/): www.bppkd.com eplanning.sumutprov.

(n.d.). https://eplanning.sumutprov.go.id/backend /web/index.php . Retrieved Juni 10, 2020, from

https://eplanning.sumutprov.go.id/backend /web/index.php diakses tanggal 10\2 Juni 2020:

https://eplanning.sumutprov.go.id/backend /web/index.php 